\title{
EVALUATION OF POTENTIAL IMPACT OF SOIL SCARIFICATION PATTERN ON TREES' DAMAGES IN FUTURE COMMERCIAL THINNING
}

\author{
Santa Kalēja, Gints Spalva, Andis Lazdin̄š \\ Latvian State Forest Research Institute 'Silava', Latvia \\ Santa.Kaleja@silava.lv
}

\begin{abstract}
The aim of the study is to analyse the empirical data collected in 2017, explaining the distribution of mechanically damaged trees left after the commercial thinning, in order to characterize the potential impact of the change of soil scarification working direction on the intensity of damage to the trees left in the felling during the following pre-commercial thinning. The study found that extraction or leaving logging residues in the felling area did not significantly affect the productivity of the soil scarification, but in areas where logging residues were extracted, the depth of the furrows increased significantly, implying a better quality of soil preparation in these areas. The study did not identify the correlation between strip-road patterns (combined or uncoupled ends) with damage intensity, but the research hypothesis was confirmed that the number and proportion of damaged trees is significantly increasing at the ends of the technological corridors. A bigger increase of proportion of damaged trees at the end of strip-roads was found in pine stands. When modelling the effect of soil preparation and logging design on the proportion of damaged trees, species specific parameters should be used - the proportion of damaged trees at the corridor ends in pine stands is $68 \%$, in spruce stands - $45 \%$ compared to the rest of the stand. The rest of the stand can be characterized by production statistics or by the results of the study - the average proportion of damaged trees in spruce stands is $4.9 \%$ and in pine stands $-0.8 \%$ of the remaining trees.
\end{abstract}

Key words: soil scarification, thinning, productivity, damages.

\section{Introduction}

Thinning is aimed to increase the profitability of forestry, while at the same time not impairing the growth conditions in the stand, therefore the planning of thinning is crucial for the future development of the stand. Soil preparation method also influences the further development of the stand. Comparing site mounding and disc trenching, the results obtained in Norway spruce (Picea abies) and Scots Pine (Pinus sylvestris) stands show that samplings planted on mounds forming deeper root system but in trenched sites the root system is formed parallel to the furrow (Celma et al., 2019). Another study concluded that planting on mounds ensured higher productivity of Norway spruce and had no negative effect on quality or efficiency on thinning (Dzerina et al., 2016). The quality of thinning is greatly influenced by the technical characteristics of the logging machines, as well as the capabilities and skills of the operators. The balance between productivity and damages to the remaining trees needs to be found. It is also important to carry out forwarding in such a way as to make as little damage as possible to the stems and roots. The risk of damages during winter is smaller than in the rest of the time. In Finland, research has shown that the risk of trunk and root damages is decreasing when working shorter shifts, as well as by performing thinning only during daylight hours. The risk of root damage is reduced by putting residues to strip-roads (Uusitalo, 2010).

Damages to the remaining trees, which affect the inner bark or deeper stem layers, can lead to the formation of a dry area and promote the decomposition (Shigo \& Shigo, 1974), or significantly increase the risk of root rot infection, especially if the damages are in the root neck area. There is a very high $(100 \%)$ likelihood of being infected with a root rot if the damaged area at the root neck area is at least $200 \mathrm{~cm}^{2}$. The risk of infection is proportional to the area of damage. Although larch, oak and pine are not susceptible to the root rot infection, trees of these species suffer from the growth disturbances due to mechanical damages. But pine and spruce are susceptible to root rot infection, so the risk of infection is high even at relatively small trunk damage. According to research conducted in Finland, a $100 \mathrm{~cm}^{2}$ bark abrasion results in $40 \%$ risk of being infected with a root rot that spreads further down the trunk about $20 \mathrm{~cm}$ per year (Isomäki \& Kallio, 1974). The risk of spreading infection is largely influenced by the season, place and species of trees. Similarly, studies show that if the stem size ranges from 5 to $10 \mathrm{~cm}$ and from 17 to $35 \mathrm{~cm}$, the growth of decayed trees over the next 10 years decreases by $13 \%$ and $35 \%$, respectively. If the damages are at the root neck area, the impact on tree growth is more significant (Isomäki \& Kallio, 1974). $70 \%$ of the roots are in the humus layer at $3-10 \mathrm{~cm}$ depth, therefore root damages during harvesting are unavoidable. Root lesions larger than $20 \mathrm{~mm}$ and closer than $0.7 \mathrm{~m}$ to the stem may become the site of infection of the root rot. Damages of the long marginal roots cause lasting effects on the growth, reducing it by up to $50 \%$, but the possibility of the root rot infection entering the root lesions is twice as large as that of the trunk (Isomäki \& Kallio, 1974). Earlier studies have shown 
that trees growing on the edges of strip-roads have less growth than the remaining trees in the forest stand, which is likely associated with damage to the root system caused by logging techniques (Bredberg \& Wästerlund, 1983; Eliasson \& Wästerlund, 2007; Wästerlund, 1989). The growth is actually affected by the cumulative effect of lesions, which combine root damage and soil compaction on strip-roads (Prindulis, Kaleja, \& Lazdins, 2016), but there will be a lack of research to demonstrate the impact of each type of damage.

In earlier experiments in Latvia, comparing the effect of strip-road density in delayed pre-commercial thinning, it was found that the average number of trees damaged in deciduous and coniferous stands is $7 \%$ of the total number of trees left. Coniferous stands had a relatively higher (2.7 times) proportion of root damage than deciduous stands. Thinning in coniferous stands in the trials was carried out in late autumn, which can be one of the main reasons for the relatively high proportion of damaged trees. In general, the rate of damaged trees in coniferous stands were by $21 \%$ less than in deciduous stands, which can be explained by the relatively high number of trees left (by $34 \%$ on average), respectively, the study shows a correlation between the total number of trees left and the number of trees damaged; in conifers, the correlation between the total number of trees left and the share of damaged trees has not been found. The largest proportion $(25 \%)$ of damaged trees was found in conifers with $10 \mathrm{~m}$ between strip-roads, and the smallest - with $15 \mathrm{~m}$ between strip-roads. No correlation was found between damage to the trees left and the pattern of strip-roads. In conifers, a higher proportion of root damage was found in the stands where the width of the strip-roads is comparatively small (Kalēja et al., 2014; Petaja, Muižnieks, \& Kalēja, 2017). The aim of the study is to analyse the empirical data collected in 2017, explaining the distribution of mechanically damaged trees left after the commercial thinning, in order to characterize the potential impact of the change of soil scarification working direction on the intensity of damage to the trees left in the felling during the following pre-commercial thinning.

\section{Materials and Methods}

The goal of time studies of soil tillage is to characterize the impact of logging residues on the productivity and time spent on maneuvers at the end of the furrows. Soil scarification time studies were done in 28 ha area, including 21 ha of Myrtillosa, Hylocomiosa and Myrtilloso-sphagnosa forest types on loamy soils and 7 ha in Aegipodiosa forest type on clay soils. Harvesting residues are laid on strip-roads in 17.6 ha and extracted in 10.4 ha area. Time studies are done during the daylight without interrupting the work process. The time while engine is switched on is recorded. The rest of the time is interrupted in time recording. At the start and end of the working day, the notes record the time when the job was started and completed. The working cycle is split by a single path, respectively; a new cycle begins at a turning point.

Mechanical damages of residual trees are counted in 77 ha of coniferous stands, where the prevalence of the dominant species (spruce or pine) is at least $70 \%$. The average age of the stands is 37 years. At least $300 \mathrm{~m}$ long compartments with regular shape with low edge clearance (the smallest enclosure of the rectangle is at least $70 \%$ filled). In 2016, all stands were harvested in commercial thinning. The total length of the surveyed strip-roads is $31.2 \mathrm{~km}$.

Location and type of damage of the remaining trees is recorded from the beginning of the strip-road in perpendicular to the longitudinal axis of the striproad, as well as damage to the type of trunk or root. The counted damaged trees are marked with colour to avoid double counting. Each damaged tree is characterized by the number of the stand and striproad, as well as the distance of the damaged tree from the beginning of the strip-road. Mechanical damage to undergrowth trees is not accounted. The starting point of each strip-road is always chosen at the side of the landing point.

\section{Results and Discussion}

A total driven distance during the soil scarification trials is $116 \mathrm{~km}$. The average speed during the soil scarification is $2.93 \pm 0.02 \mathrm{~km} \mathrm{~h}^{-1}$. Outside the manoeuvring belts, the rate increases statistically significantly - up to $2.97 \pm 0.01 \mathrm{~km} \mathrm{~h}^{-1}$. The study did not detect significant differences in speed, depending on whether the harvesting residues are removed or left in a stand. The average mileage per 1 ha is $4.9 \mathrm{~km}$ (for more complex configurations - up to $8.5 \mathrm{~km} \mathrm{ha}^{-1}$, i.e. twice more than the average). The average depth of the furrow is $19 \mathrm{~cm}(15-21 \mathrm{~cm})$. When logging residues were extracted, on average, $43 \mathrm{~min}$ of productive time were spent per $1 \mathrm{ha}$, if the harvesting residues are left in strip-roads - $37 \mathrm{~min}$, excluding driving in and out of the stand. The difference is not statistically significant due to variation of the data. Comparing working time consumption for soil preparation in Myrtillosa and Aegipodiosa stand types, no significant differences have been found, although the consumption of productive working time for soil scarification in areas where logging residues are not extracted is slightly smaller than in areas where harvesting residues have been removed, respectively, $38 \mathrm{~min} \mathrm{ha}^{-1}$ and $44 \mathrm{~min} \mathrm{ha}^{-1}$.

Most of the working time (79\%) in the trials was used for the operation 'soil preparation', $12 \%$ of working time was spent on manoeuvring at the end of the furrows. The average manoeuvring time at the 
end of each path is 20 seconds. In areas where logging residues have been removed, the manoeuvring at the end of each path averaged in 21 seconds, but in areas where logging residues left in strip-roads $-20 \mathrm{sec}$. The difference is not statistically significant when comparing different forest stand types and forest stands where the residues are extracted or left in strip-roads. The average distance between the paths is $4.8 \pm 0.2 \mathrm{~m}$. The average depth of the furrows is $18.6 \pm 0.3 \mathrm{~m}$ (from $15.4 \pm 0.4 \mathrm{~m}$ to $20.9 \pm 1.4 \mathrm{~m}$ ). The distance between the paths in the areas where the residues are left in strip-roads or extracted does not differ significantly. The average depth of the furrows in areas, where the residues are left in strip-roads, is $17.5 \pm 0.4 \mathrm{~cm}$, and in the areas where the residues are extracted $-19.7 \pm 0.4 \mathrm{~cm}$. The difference is statistically significant; the extraction of the residues improves the quality of soil preparation without significantly impairing productivity. The monitoring of forest regeneration has to be continued to find if there is a positive correlation between the depth of furrows and forest regeneration results in the long term.

The average number of damaged trees is $2.34 \%$, including $2.22 \%$ outside the manoeuvring belts and $3.15 \%$ in the manoeuvring belts. The increase in the proportion of the damages in the manoeuvring belts (15 $\mathrm{m}$ from the edge of the felling area) is $41.9 \%$.
The increase in the share of the damages in different stands varies, in 6 out of 20 stands the damages at the ends of the strip-roads are not increasing. There were no stands where the number of damaged trees reduces at the ends of the strip-roads. Comparing the proportion of damaged trees in stands where the striproads are connected at the end or not connected no significant difference has been found. In spruce stands the increase in the damages at the ends of the striproads is not statistically significant; however the total proportion of damaged trees in stands where the striproads are connected is bigger.

The increase in the proportion of damaged trees is significant in pine stands. At the same time, no increase in the proportion of root damage has been found in pine stands. Weighted values have been prepared for the calculation model, taking into account the length of the strip-roads. In the pine stands included in the study, the weighted average proportion of mechanically damaged trees is $0.8 \%$, in spruce stands $-4.9 \%$. The increase of proportion of damaged trees in the manoeuvring belts compared to the rest of the stand is $68 \%$ in pine stands and $45 \%$ in spruce stands. The number and proportion of damaged trees in the 100 -meter-long segment of strip-road in pine stands do not differ significantly, regardless of the length of the strip-road, although there is a tendency for the

\section{Activity data for calculation of length of strip-roads and soil scarification paths}

Table 1

\begin{tabular}{|c|c|c|c|}
\hline Parameter & Symbol & Unit & Notes / default values \\
\hline \multicolumn{4}{|l|}{ Soil scarification } \\
\hline Distance between paths & $\mathrm{d}$ & $\mathrm{m}$ & 4.8 \\
\hline Mineralized area & MJ & $\mathrm{M}^{2} \mathrm{~m}^{-1}$ & 1 \\
\hline Width of compartment & $\mathrm{aD}$ & $\mathrm{m}$ & 100 \\
\hline Length of compartment & $\mathrm{ab}$ & $\mathrm{m}$ & 500 \\
\hline Angle of furrows against axis & $\alpha$ & degrees & $0-90^{\circ}$ \\
\hline Length of turning line & $\mathrm{S}_{\text {apgr }}$ & $\mathrm{m}$ & 28 \\
\hline Driving speed & $\mathrm{V}$ & $\mathrm{km} \mathrm{h}^{-1}$ & 3 \\
\hline \multicolumn{4}{|l|}{ Thinning } \\
\hline Distance between strip-roads & $\mathrm{d}$ & $\mathrm{m}$ & 20 \\
\hline Width of strip-roads & $\mathrm{p}$ & $\mathrm{m}$ & 4 \\
\hline Number of remaining trees in stand & $\mathrm{N}_{\mathrm{s}}$ & No. ha ${ }^{-1}$ & 800 \\
\hline Dominant species & - & - & Spruce or pine can be selected \\
\hline Diameter of average tree & $\mathrm{D}_{1.3}$ & $\mathrm{~cm}$ & 18 \\
\hline Height of average tree & $\mathrm{H}$ & $\mathrm{m}$ & 16 \\
\hline Share of damaged trees outside manoeuvring belts & $\mathrm{BK}_{1}$ & - & $4 \%$ \\
\hline Share of damaged trees inside manoeuvring belts & $\mathrm{BK}_{2}$ & - & $31 \%$ \\
\hline Angle of corridors against stand axle & $\alpha_{1}$ & degrees & $\alpha_{1}=\alpha+45^{o}$ \\
\hline Width of turning belt of forwarder & $\mathrm{d}_{3}$ & $\mathrm{~m}$ & 15 \\
\hline
\end{tabular}


number and proportion of damaged trees decrease with an increase of the length of strip-roads. A similar trend has also been found in spruce stands.

The study involves felling sites extracted by various contractors, which probably had a significant impact on the results of the study, increasing the uncertainty of the calculated relationships. In order to characterize the impact of operator experience on these indicators, it is useful to carry out random sampling in subsequent studies, using automated data storage devices for recording of rut depth and stand composition. The results of such a study can be used to improve the training programs for operators and company managers.

Moderate correlation between density (basal area and number of trees) of a stand and the damaged

\section{Equations for calculation of productivity of soil scarification}

\begin{tabular}{|c|c|c|c|}
\hline Parameter & Symbol & Unit & Notes / default values \\
\hline \multirow{2}{*}{ Turning distance } & $\mathrm{S}_{\text {nog. }}$ & ha & $S_{\text {nog. }}=\frac{\mathrm{aD} * \mathrm{ab}}{10000}$ \\
\hline & $\mathrm{S}_{\mathrm{ABCD}}$ & ha & $S_{\mathrm{ABCD}}=\frac{\mathrm{ab} *(\mathrm{aD}+\mathrm{Aa})}{10000}$ \\
\hline \multicolumn{4}{|l|}{ Angle against axis of a stand $1^{\circ}-90^{\circ}$} \\
\hline Distance between paths & $d^{2}$ & $\mathrm{~m}$ & $d_{2}=\frac{d}{\sin \left(\operatorname{radians}\left(\operatorname{if}\left(\alpha>90^{\circ} ; 180^{\circ}-\alpha ; \alpha\right)\right)\right)}$ \\
\hline Length of straight path & $\mathrm{AB}$ & $\mathrm{m}$ & $\mathrm{AB}=\frac{\mathrm{ab}}{\sin (\operatorname{radians}(\alpha))}$ \\
\hline$\beta$ angle & $\beta$ & degrees & $\beta=360^{\circ}-90^{\circ}-\alpha$ \\
\hline Cathetus of rectangle triangle & Aa & $\mathrm{m}$ & $\mathrm{Aa}=\tan (\operatorname{radians}(\beta)) * \mathrm{ab}$ \\
\hline Number of paths & $\mathrm{N}_{\mathrm{AB}}$ & No. & $N_{\mathrm{AB}}=\operatorname{roundup}\left(\frac{\mathrm{Aa}+\mathrm{aD}}{d_{2}}\right)$ \\
\hline Total length of straight paths in parallelogram & $\mathrm{s}_{1}$ & $\mathrm{~m}$ & $s_{1}=\mathrm{AB} * A_{\mathrm{AB}}$ \\
\hline Total length of straight paths in compartment & $\mathrm{s}_{2}$ & $\mathrm{~m}$ & $S_{2}=\frac{S_{\text {nog. }}}{S_{\mathrm{ABCD}}} * S_{1}$ \\
\hline Theoretical driving distance in compartment & $\mathrm{S}_{3}$ & $\mathrm{~m}$ & $s_{3}=\left(\left(N_{\mathrm{AB}}-1\right) * S_{\text {apgr. }}\right)+s_{2}$ \\
\hline Driving distance & $\mathrm{S}_{4}$ & $\mathrm{~m} \mathrm{ha}^{-1}$ & $S_{4}=\frac{S_{3}}{S_{\text {nog. }}}$ \\
\hline Time consumption & $\mathrm{t}$ & $h h^{-1}$ & $t=\frac{\frac{s_{4}}{1000}}{v}$ \\
\hline Mineralized area & $t_{1}$ & ha ha- ${ }^{-1}$ & $t_{1}=\frac{s_{4} * \mathrm{MJ}}{10000}$ \\
\hline \multicolumn{4}{|l|}{ Angle against axis of a stand $0^{\circ}$} \\
\hline Number of straight paths & $\mathrm{N}_{\mathrm{ab}}$ & No. & $N_{\mathrm{ab}}=\operatorname{roundup}\left(\frac{\mathrm{ab}}{d}\right)$ \\
\hline Length of straight paths in compartment & $\frac{s_{1}}{s_{2}}$ & $\mathrm{~m}$ & $\frac{s_{1}}{s_{2}}=N_{\mathrm{ab}} * \mathrm{aD}$ \\
\hline Theoretical driving distance in compartment & $\mathrm{S}_{3}$ & $\mathrm{~m}$ & $S_{3}=\left(N_{\mathrm{ab}}-1\right) * S_{\text {apgr. }}+\frac{S_{1}}{S_{2}}$ \\
\hline Driving distance & $\mathrm{S}_{4}$ & $\mathrm{~m} \mathrm{ha}^{-1}$ & $S_{4}=\frac{S_{3}}{S_{\text {apgr. }}}$ \\
\hline Time consumption & $\mathrm{t}$ & $\mathrm{h} \mathrm{ha}^{-1}$ & $t=\frac{\frac{S_{4}}{1000}}{v}$ \\
\hline Mineralized area & $\mathrm{t}_{1}$ & ha ha ${ }^{-1}$ & $t_{1}=\frac{s_{4} * \mathrm{MJ}}{10000}$ \\
\hline
\end{tabular}


trees was found in both pine and spruce stands after thinning. The correlation is characterized by a linear regression equation. No correlation has been found between the number of damaged trees and the residual basal area. This is in line with the advice of scientists to leave fewer trees during early thinning to produce larger-sized trunks in regenerative felling, thus reducing the number of damaged trees in thinning, too. In the calculation model, the relationship between the number of trees and the proportion of damaged trees is not taken into account, as the elaboration of a sufficiently accurate equation requires about 3 times larger number of the test objects. The results of the study are summarized in a model, which allows calculating the influence of the direction of soil preparation or tree columns on the productivity of soil preparation and damage of the leaves left in the regular shape stands. Table 1 lists the activity data necessary for the calculations.

The calculation of time consumption for scarification of 1 ha is summarized in Table 2 . Depending on the angle of the soil preparation direction, relative to the base of the compartment, the calculation is divided into 2 scenarios $-1-90^{\circ}$ and $0^{\circ}$. In the calculation, the selection of the scenario takes place automatically, depending on the parameters entered in the activity data table. Equations for calculation of share of trees damaged during thinning and length of strip-roads as well as other parameters are provided in Tables 3 and 4.

Table 3

\section{Equations for calculation of share of trees damaged during thinning and length of strip-roads}

\begin{tabular}{|c|c|c|c|}
\hline Parameter & Symbol & Unit & Notes / values \\
\hline Angle of corridors against axle of compartment & $\alpha$ & degrees & $\alpha=\alpha_{\text {soil scarification }}+45^{\circ}$ \\
\hline \multirow[t]{2}{*}{ Width of manoeuvring belt } & $\mathrm{S}_{\text {nog. }}$ & ha & $S_{\text {nog. }}=\frac{\mathrm{aD}}{\mathrm{ab}}$ \\
\hline & $\mathrm{S}_{\mathrm{ABCD}}$ & ha & $S_{\mathrm{ABCD}}=\frac{\mathrm{ab} *(\mathrm{aD}+\mathrm{Aa})}{10000}$ \\
\hline \multicolumn{4}{|c|}{ Angle of corridors against axle of compartment is $1^{\circ}-90^{\circ}$} \\
\hline $\begin{array}{l}\text { Distance between corridors at the bottom of } \\
\text { compartment }\end{array}$ & $d_{2}$ & $\mathrm{~m}$ & $d_{2}=\frac{d}{\sin \left(\operatorname{radians}\left(\operatorname{if}\left(\alpha>90^{\circ} ; 180^{\circ}-\alpha ; \alpha\right)\right)\right)}$ \\
\hline Length of straight path in strip-road & $\mathrm{AB}$ & $\mathrm{m}$ & $d_{2}=\frac{d}{\sin \left(\operatorname{radians}\left(\operatorname{if}\left(\alpha>90^{\circ} ; 180^{\circ}-\alpha ; \alpha\right)\right)\right)}$ \\
\hline$\beta$ angle & $\beta$ & degrees & $\beta=390^{\circ}-90^{\circ}-\operatorname{if}\left(\alpha>90^{\circ} ; 180^{\circ}-\alpha ; \alpha\right)$ \\
\hline Cathetus of rectangle triangle & $\mathrm{Aa}$ & $\mathrm{m}$ & $\mathrm{Aa}=\tan (\operatorname{radians}(\beta)) * \mathrm{ab}$ \\
\hline Number of straight paths & $\mathrm{N}_{\mathrm{AB}}$ & No. & $N_{\mathrm{AB}}=\operatorname{roundup}\left(\frac{\mathrm{Aa}+\mathrm{aD}}{d_{2}}\right)$ \\
\hline Length of straight paths in the smallest triangle & $\mathrm{s}_{1}$ & $\mathrm{~m}$ & $s_{1}=\mathrm{AB} * N_{\mathrm{AB}}$ \\
\hline Length of straight paths in the compartment & $\mathrm{S}_{2}$ & $\mathrm{~m}$ & $S_{2}=\frac{S_{\text {nog. }}}{S_{\mathrm{ABCD}}} * S_{1}$ \\
\hline Length of strip-road & $\mathrm{S}_{4}$ & $\mathrm{~m} \mathrm{ha}^{-1}$ & $S_{4}=\frac{S_{2}}{S_{\text {nog. }}}$ \\
\hline Length of manoeuvring path & $\mathrm{d}_{4}$ & $\mathrm{~m}$ & $d_{4}=\frac{d_{3}}{\sin \left(\operatorname{radians}\left(\left(\operatorname{if}\left(\alpha>90^{\circ} ; 180^{\circ}-\alpha ; \alpha\right)\right)\right)\right.}$ \\
\hline Length of manoeuvring paths in compartment & $\mathrm{d}_{4 \text { nog. }}$ & $\mathrm{m}$ & $d_{4 \text { nog. }}=d_{4} * N_{\mathrm{AB}} * 2$ \\
\hline Length of manoeuvring paths per area unit & $\mathrm{d}_{4 \mathrm{ha}}$ & $\mathrm{m}$ & $d_{4 \mathrm{ha}}=\frac{d_{4 \text { nog. }}}{S_{\text {nog. }}}$ \\
\hline Area of manoeuvring paths & $\mathrm{s}_{\text {apgr. }}$ & $\mathrm{m}^{2}$ & $S_{\text {apgr. }}=\frac{d_{2}}{d_{3}}$ \\
\hline Number of manoeuvring paths in compartment & $\mathrm{n}_{\text {apgr. nog. }}$ & No. & $n_{\text {apgr.nog. }}=N_{\mathrm{AB}} * 2$ \\
\hline
\end{tabular}




\begin{tabular}{|c|c|c|c|}
\hline Parameter & Symbol & Unit & Notes / values \\
\hline Area of manoeuvring paths in compartment & $\mathrm{S}_{\text {apgr. }}$ & ha & $S_{\text {apgr. }}=\frac{n_{\text {apgr.nog. }} * S_{\text {apgr. }}}{10000}$ \\
\hline Area of manoeuvring paths per area unit & $\mathrm{S}_{\text {apgr. ha }}$ & ha ha ${ }^{-1}$ & $S_{\text {apgr.ha }}=\frac{S_{\text {apgr. }}}{S_{\text {nog. }}}$ \\
\hline Area of strip-roads & $\mathrm{K}_{\text {nog. }}$ & ha & $K_{\text {nog. }}=\frac{s_{2} * p}{10000}$ \\
\hline Share of area of strip-roads & $\mathrm{K}_{\text {nog. } \%}$ & - & $K_{\text {nog. }}=\frac{k_{\text {nog. }}}{S_{\text {nog. }}}$ \\
\hline \multicolumn{4}{|l|}{ Angle of corridors against axle of compartment is $0^{\circ}$} \\
\hline Number of straight paths & $\mathrm{N}_{\mathrm{ab}}$ & No. & $N_{\mathrm{ab}}=\operatorname{roundup}\left(\frac{\mathrm{ab}}{d}\right)$ \\
\hline Length of straight paths per compartment & $\frac{S_{1}}{S_{2}}$ & $\mathrm{~m}$ & $\frac{s_{1}}{s_{2}}=N_{\mathrm{ab}} * \mathrm{aD}$ \\
\hline Distance driven & $\mathrm{S}_{4}$ & $\mathrm{~m} \mathrm{ha}^{-1}$ & $S_{4}=\frac{\frac{S_{1}}{S_{2}}}{S_{\text {nog. }}}$ \\
\hline Length of manoeuvring path & $d_{4}$ & $\mathrm{~m}$ & $d_{4}=d_{3}$ \\
\hline Length of manoeuvring paths in compartment & $\mathrm{d}_{4 \text { nog. }}$ & $\mathrm{m}$ & $d_{4 \text { nog. }}=d_{4} * N_{\mathrm{ab}} * 2$ \\
\hline Length of manoeuvring paths per area unit & $\mathrm{d}_{4 \text { ha }}$ & $\mathrm{m}$ & $d_{4 \mathrm{ha}}=\frac{d_{4 \mathrm{nog} .}}{S_{\text {nog. }}}$ \\
\hline Area of manoeuvring paths & $\mathrm{S}_{\text {apgr. }}$ & $\mathrm{m}^{2}$ & $s_{\text {apgr. }}=d_{4} * d$ \\
\hline Number of manoeuvring paths in compartment & $\mathrm{n}_{\text {apgr. nog. }}$ & No. & $n_{\text {apgr.nog. }}=N_{\mathrm{ab}} * 2$ \\
\hline Area of manoeuvring paths in compartment & $\mathrm{S}_{\text {apgr. }}$ & ha & $S_{\text {apgr. }}=\frac{n_{\text {apgr.nog. }} * S_{\text {apgr. }}}{10000}$ \\
\hline Area of manoeuvring paths per area unit & $\mathrm{S}_{\text {apgr. ha }}$ & ha ha ${ }^{-1}$ & $S_{\text {apgr.ha }}=\frac{S_{\text {apgr. }}}{S_{\text {nog. }}}$ \\
\hline Area of strip-roads & $\mathrm{K}_{\text {nog. }}$ & ha & $K_{\text {nog. }}=\frac{\frac{s_{1}}{S_{2}} * p}{10000}$ \\
\hline Share of area of strip-roads & $\mathrm{K}_{\text {nog. } \%}$ & - & $K_{\text {nog. }}=\frac{K_{\text {nog. }}}{S_{\text {nog. }}}$ \\
\hline \multicolumn{4}{|l|}{ Calculation of share of damaged trees } \\
\hline Height coefficient & $\mathrm{VH}$ & - & $\begin{array}{l}\text { Regulations of Cabinet of Ministers No 228, } \\
07.03 .2003\end{array}$ \\
\hline Basal area & G & $\mathrm{m}^{2} \mathrm{ha}^{-1}$ & $G=\frac{D_{1,3}^{2} * \pi}{10000} * N_{s}$ \\
\hline Growing stock & M & $\mathrm{m}^{3} \mathrm{ha}^{-1}$ & $M=\mathrm{VH} * G$ \\
\hline Average tree & $\mathrm{M}_{\text {vid. }}$ & $\mathrm{m}^{3}$ & $M_{\text {vid. }}=\frac{M}{N_{s}}$ \\
\hline Basal area of damaged trees & $\mathrm{G}_{\mathrm{B}}$ & $\mathrm{m}^{2} \mathrm{ha}^{-1}$ & $G_{B}=G_{\text {Bamj }}+G_{\text {Bmj }}$ \\
\hline Growing stock of damaged trees & $\mathrm{M}_{\mathrm{b}}$ & $\mathrm{m}^{3}$ ha $^{-1}$ & $M_{B}=M_{\mathrm{Bamj}}+M_{\mathrm{Bmj}}$ \\
\hline Number of damaged trees & $\mathrm{N}_{\mathrm{B}}$ & No. ha ${ }^{-1}$ & $N_{B}=N_{\text {Bamj }}+N_{\text {Bmj }}$ \\
\hline Share of damaged trees & $\mathrm{N}_{\mathrm{B} \%}$ & & $N_{\mathrm{B} \%}=\frac{N_{B}}{N_{S}}$ \\
\hline
\end{tabular}




\section{Calculation of damaged trees in thinning}

\begin{tabular}{|c|c|c|c|c|}
\hline Parameter & Symbol & Unit & Manoeuvring belts & Outside manoeuvring belts \\
\hline Basal area & $\mathrm{G}_{\mathrm{mj}}$ & $\mathrm{m}^{2} \mathrm{ha}^{-1}$ & $G_{\mathrm{mj}}=\frac{G * S_{\text {apgr. }}}{S_{\text {nog. }}}$ & $G_{\mathrm{amj}}=G-G_{\mathrm{mj}}$ \\
\hline Growing stock & $\mathrm{M}_{\mathrm{mj}}$ & $\mathrm{m}^{3} \mathrm{ha}^{-1}$ & $M_{\mathrm{mj}}=\frac{M * S_{\text {apgr. }}}{S_{\text {nog. }}}$ & $M_{\mathrm{amj}}=M-M_{\mathrm{mj}}$ \\
\hline Number of trees & $\mathrm{N}_{\mathrm{mj}}$ & No. ha ${ }^{-1}$ & $N_{\mathrm{mj}}=\frac{N * S_{\text {apgr. }}}{S_{\text {nog. }}}$ & $N_{\mathrm{amj}}=N-N_{\mathrm{mj}}$ \\
\hline Basal area of damaged trees & $\mathrm{G}_{\mathrm{Bmj}}$ & $\mathrm{m}^{2} \mathrm{ha}^{-1}$ & $G_{\mathrm{Bmj}}=G_{\mathrm{mj}} * \mathrm{BK}_{1} *\left(1+\mathrm{BK}_{2}\right)$ & $G_{\mathrm{Bamj}}=G_{\mathrm{amj}} * \mathrm{BK}_{1}$ \\
\hline Growing stock of damaged trees & $\mathrm{M}_{\mathrm{B} \mathrm{mj}}$ & $\mathrm{m}^{3} \mathrm{ha}^{-1}$ & $M_{\mathrm{Bmj}}=M_{\mathrm{mj}} * \mathrm{BK}_{1} *\left(1+\mathrm{BK}_{2}\right)$ & $M_{\mathrm{Bamj}}=M_{\mathrm{amj}} * \mathrm{BK}_{1}$ \\
\hline Number of damaged trees & $\mathrm{N}_{\mathrm{Bmj}}$ & No. ha ${ }^{-1}$ & $N_{\mathrm{Bmj}}=N_{\mathrm{mj}} * \mathrm{BK}_{1} *\left(1+\mathrm{BK}_{2}\right)$ & $N_{\text {Bamj }}=N_{\text {amj }} * \mathrm{BK}_{1}$ \\
\hline
\end{tabular}

The difference between the maximum and minimum predicted share of damaged trees is $0.42 \%$ (from $4.18 \%$ to $4.60 \%$ ). The area occupied by the striproads (assuming a corridor width is $4 \mathrm{~m}$ ) is $20-22 \%$, depending on the slope of the strip-roads. The study proved that the variation of the share of damaged trees depending on the direction of the strip-road relative to the longitudinal axis of the compartment, is negligible, therefore the adaptation of the soil scarification pattern to optimize direction of strip-roads in later thinning, is not necessary and a design providing the lowest cost should be selected in soil scarification if no other requirements are set. The potential economic benefits because of a decrease in the proportion of damaged trees due to optimization of pattern of strip-roads do not outweigh the additional costs for soil scarification. In the example provided in this paper it is assumed that the quality of damaged trees is deteriorating and only the assortment of firewood can be produced from damaged trees and the remaining growing stock after the thinning is $164 \mathrm{~m}^{3} \mathrm{ha}^{-1}$, including $6.9-7.3 \mathrm{~m}^{3}$ $\mathrm{ha}^{-1}$ of mechanically damaged trees, and the average tree is $0.21 \mathrm{~m}^{3}$. AGM model is used in calculation of the stock changes (Šnepsts et al., 2018), assuming that the $2^{\text {nd }}$ thinning is done 20 years after the $1^{\text {st }}$ thinning and $60 \mathrm{~m}^{3} \mathrm{ha}^{-1}$ including all damaged trees are extracted. Calculations of assortments were done according to the JSC 'Latvijas valsts meži' guidelines (AS 'Latvijas valsts meži', 2010). 48\% of the volume will be saw logs and small logs, $41 \%$ paper pulp and $11 \%$ firewood. The difference in potential earnings in thinning is $8 \mathrm{EUR} \mathrm{ha}^{-1}$, according to the prices of the round timber assortments available in the Central Statistical Bureau of 2018. Productivity of soil scarification in a regular configuration compartment, depending on the direction of soil scarification, varies by $7 \%$, i.e. at an average soil preparation cost of 160 EUR $\mathrm{ha}^{-1}$, the maximum theoretical cost deviation is 11.2 EUR ha $\mathrm{E}^{-1}$, i.e. more than the benefit due to reduction of the number of damaged trees.

\section{Conclusions}

1. The productivity of soil preparation in the study areas is not significantly affected by growing conditions and the presence of logging residues on strip-roads. The average time consumption per ha is $44 \mathrm{~min}$, including $12 \%$ of time spent on manoeuvring at a perimeter of a stand.

2. The average distance between furrows does not differ, regardless of whether the logging residues are on strip-roads or extracted; in turn, the impact on the depth of the furrow is significant extraction of the residues significantly increases the depth of the furrow improving the quality of the soil scarification.

3. The share of damaged trees at the ends of the striproads increases in the thinning significantly. The average increase in the proportion of damaged trees at the ends of the strip-roads compared to the rest of the strip-road increases by $45 \%$ in spruce stands and by $68 \%$ in pine stands.

4. The calculation model developed in the study proves that adapting the soil preparation design to the optimal placement of the strip-roads in thinning to be carried out 20-30 years after the soil preparation is not useful unless determined by nature protection or other conditions.

\section{Acknowledgements}

The study is implemented within the scope of the memorandum between LSFRI Silava and Joint Stock Company 'Latvia state forests' from 11.10.2011. 


\section{References}

1. AS 'Latvijas valsts meži'. (2010). Sortimentu iznākums galvenajā un krājas kopšanas cirtē (Production of assortments in final felling and thinning). (in Latvian)

2. Bredberg, C.-J., \& Wästerlund, I. (1983). Wurzel und Bodenschäden durch Fahrzeuge (Vehicle-caused damage to roots and soil). Forstwissenschaftliches Centralblatt, 102(1), 86-98. DOI: 10.1007/BF02741842. (in German)

3. Celma, S., Blate, K., Lazdiņa, D., Dūmiņš, K., Neimane, S., Štāls, T.A., \& Štikāne, K. (2019). Effect of soil preparation method on root development of $P$. sylvestris and $P$. abies saplings in commercial forest stands. New Forests, 50(2), 283-290. DOI: 10.1007/s11056-018-9654-4.

4. Dzerina, B., Girdziusas, S., Lazdina, D., Lazdins, A., Jansons, J., Neimane, U., \& Jansons, Ā. (2016). Influence of spot mounding on height growth and tending of Norway spruce: case study in Latvia. Forestry Studies, 65, 24-33. DOI: 10.1515/fsmu-2016-0009.

5. Eliasson, L., \& Wästerlund, I. (2007). Effects of slash reinforcement of strip roads on rutting and soil compaction on a moist fine-grained soil. Forest Ecology and Management, 252(1-3), 118-123. DOI: 10.1016/j.foreco.2007.06.037.

6. Isomäki, A., \& Kallio, T. (1974). Consequences of injury caused by timber harvesting machines on the growth and decay of spruce (Picea abies (L.) Karst.). Acta Forestalia Fennica 136(136), DOI: 10/gftqmq.

7. Kalēja, S., Zimelis, A., Prindulis, U., \& Lazdin̄š, A. (2014). Tehnoloǵisko koridoru izvietojuma blīvuma novērtēšana savlaicīgā un novēlotā jaunaudžu kopšanā (Evaluation of impact of density of strip-roads in timely and delayed pre-commercial thinning). Salaspils. LVMI 'Silava'. (2014-07). (in Latvian)

8. Petaja, G., Muižnieks, E., \& Kalēja, S. (2017). Efficiency of Vimek 610.2 forwarder and its impact on soil in forest thinning. Proceedings of the $8^{\text {th }}$ International Scientific Conference Rural Development 2017 , DOI: 10.15544/RD.2017.176. (in press)

9. Prindulis, U., Kaleja, S., \& Lazdins, A. (2016). Soil compaction in young stands during mechanized logging of biofuel and roundwood assortments. Research for Rural Development. International Scientific Conference Proceedings Vol. 2, (pp. 67-76). ISSN:1691-4031.

10. Shigo, A.L., \& Shigo, A. (1974). Detection of discoloration and decay in living trees and utility poles. Northeastern Forest Experiment Station Forest Service, United States, Department of Agriculture. DOC. [443.3:812.111.844]-015.7.

11. Šṇepsts, G., Kārkliṇa, I., Lupiķis, A., Butlers, A., Bārdule, A., \& Lazdin̄̌s, A. (2018). AGMmodel description (Draft No. 2018 01-1) (p. 98). Salaspils: LSFRI Silava. Retrieved February 10, 2019, from https://drive. google.com/open?id=1VeylfH2F8angICoU1QfnUGPwBI29ezBX.

12. Uusitalo, J. (2010). Introduction to forest operations and technology. JVP Forest Systems Oy. ISBN 978952-92-5269-5.

13. Wästerlund, I. (1989). Strength components in the forest floor restricting maximum tolerable machine forces. Journal of Terramechanics, 26(2), 177-182. DOI: 10/dxzvdx. 